\title{
Gold in erythrocytes, whole blood, and plasma during long-term chrysotherapy
}

\author{
S. MøLLER PEDERSEN AND P. MøLLER GRAABÆK
}

From the Rheumatism Unit, University of Aarhus, the Department of Clinical Chemistry, University Hospital of Odense, and the Institute of Cell Biology, Department of Anatomy, University of Aarhus, Denmark

SUMMARY The concentrations of gold in erythrocytes, whole blood, cell-rich plasma, and cell-free plasma were investigated in 17 patients with rheumatoid arthritis undergoing long-term chrysotherapy. Gold estimations were performed with a graphite tube atomic absorption spectrophotometer. Significant quantities of gold were found in isolated erythrocytes of 12 patients. There was no correlation between erythrocyte gold and therapeutic response, plasma gold, and gold in whole blood. Nor did gold in whole blood or plasma show any correlation with therapeutic response and toxic reaction. However, all patients (3) with toxic reactions had a significantly higher gold concentration in the erythrocytes than the patients without toxic reactions. This result indicates that erythrocyte gold estimations could provide a useful warning of impending toxic reactions.

During the 50 years gold salts have been used for the treatment of patients with rheumatoid arthritis several investigators have searched for methods to improve drug efficacy while reducing undesirable toxic effects. Especially since the introduction of atomic absorption spectroscopy, which makes routine estimation of gold in biological fluids practicable, great attention has been focused on the determination of gold in serum or plasma to obtain an objective indicator of prognosis and clinical efficacy. Most workers, however, did not find any correlation between serum or plasma gold levels and clinical effect and toxicity, ${ }^{1-8}$ though some have found such a correlation. ${ }^{9-11}$

It is possible that the concentration of gold in erythrocytes might be a better indicator of the amounts of gold accumulated in tissue than serum or plasma gold, and thereby offer a more useful test of effectiveness and toxicity of gold therapy. Little has been published on the incorporation of gold into erythrocytes, and some of what has is conflicting. ${ }^{12-14}$ The failure to find gold, or the finding of only traces, in red blood cells might be due to the methods employed or to too short treatment with gold.

For these reasons it was considered important to re-examine the concentrations of gold in erythro-

Accepted for publication 27 November 1979

Correspondence to Dr Susanne Møller Pedersen, Department of Clinical Chemistry, Odense University Hospital, DK5000 Odense, Denmark. cytes, whole blood, and plasma from patients on long-term chrysotherapy. The gold content of theos blood fractions was estimated by atomic absorption? spectrometry using graphite tube atomisation..$^{15}$ Correlations of gold in erythrocytes with whole blood and plasma gold concentrations, laboratory parameters, and toxicity are presented.

\section{Patients and methods}

Seventeen patients with rheumatoid arthritis on long-term chrysotherapy were selected for studying gold distribution in whole blood. Six patients were being treated with sodium aurothiomalate (Myocrisin) and 11 with sodium aurothiosulphate (Sanocrysin). Most patients received maintenance dose of 10 or $20 \mathrm{mg}$ Myocrisin by intramuscular injection every 2 weeks, or 25 or $50 \mathrm{mg}$ Sanocrysin by intravenous injection every 2 or 4 weeks. The cumulative dose of Myocrisin and Sanocrysin given varied from 1195 to $3100 \mathrm{mg}$ and from 1050 to $9375 \mathrm{mg}$ respectively. Ten patients were WaalerRose positive, 7 were Waaler-Rose negative. Laboratory tests performed on each patient included: haemoglobin, erythrocyte sedimentation rate (ESR), haematocrit, and leucocyte, erythrocyte, and thrombocyte counts.

Whole blood was collected immediately before the administration of a further dose of gold in heparinised $(5 \mathrm{IE} / \mathrm{ml})$ polyethylene tubes. Red blood cells were separated from cell-rich plasma by 
sedimentation for 1 hour at $4^{\circ} \mathrm{C}$. Cell-free plasma was collected from cell-rich plasma by centrifuging at $2500 \mathrm{~g}$ for 10 minutes at $4^{\circ} \mathrm{C}$. Separation procedures were monitored by thrombocyte, erythrocyte, and leucocyte counts.

Isolated erythrocytes were washed 5 times with sterile isotonic saline, and the last 2 washes were monitored for residual gold. No gold was removed by the 2 last washes. An erythrocyte count was performed on each washed erythrocyte fraction in order to calculate the amount of gold in $10 \times 10^{12}$ erythrocytes per liter. This is a very important correction which does not seem to have been appreciated.

$300 \mu \mathrm{l}$ samples in duplicate of washed erythrocytes, whole-blood, cell-rich plasma, and cell-free plasma were assayed for gold content with a flameless atomic absorption spectrophotometer (Beckman model 485 fitted with a Massman Cuvette model 1268) by the method described by Pedersen and Graabæk..$^{15}$ All samples with gold concentrations below $5 \mu \mathrm{g} / 100 \mathrm{ml}$ were re-examined with $1 \mathrm{ml}$ samples. The results were consistent with those obtained from analysis of $300 \mu \mathrm{l}$ samples. No gold (less than $0.005 \mu \mathrm{g} \mathrm{ml}^{-1}$ ) was detected in the above mentioned blood fractions from persons not receiving gold.

\section{Results}

The amounts of gold in erythrocytes, whole blood, and plasma found in 17 patients on long-term chrysotherapy are listed in Table 1 . Only gold concentrations in cell-rich plasma are displayed in the Table, as no significant difference in plasma samples with and without leucocytes and thrombocytes was seen. Each value represents the gold concentration before injection and is the average of gold estimations performed in duplicate.

The concentration of gold associated with the red blood cells ranged from 0 to $88 \mu \mathrm{g} / 100 \mathrm{ml}$ of washed erythrocyte fraction. The ability to incorporate gold into erythrocytes was the same in the seropositive and the seronegative group and was independent of whether Myocrisin or Sanocrysin was administrated. No correlation between gold in erythrocytes and administrated dose or cumulative dose was found. Nor did gold in erythrocytes show any correlation with gold in plasma and whole blood. Quantitative values for the correlation between gold in erythrocytes, whole blood, and plasma fractions and activity and toxicity were calculated by the Spearman rank correlation and the MannWhitney $U$ test (Table 2). The erythrocyte gold concentrations were found to be uncorrelated with

Table 2 Correlation of gold in washed erythrocyte fraction $(R B C)$, whole blood, and plasma with erythrocyte sedimentation rate $(E S R)$ and toxicity

\begin{tabular}{lll}
\hline & Activity (ESR) & Toxicity \\
\hline Gold in RBC $10 \times 10^{12} / 1$ & $\mathrm{r}_{\mathrm{S}}=0.14$ & $\mathrm{p}<0.01$ \\
Gold in whole blood & $\mathrm{rs}_{\mathrm{S}}=-0.09$ & $\mathrm{p}>>0.1$ \\
Gold in plasma & $\mathrm{r}_{\mathrm{S}}=0.07$ & $\mathrm{p}>>0.1$ \\
\hline
\end{tabular}

rs = Spearman rank correlation coefficient. $\quad \mathrm{p}=$ The significance leve] by the Mann-Whitney U test.

Table 1 Gold concentrations, erythrocyte sedimentation rate (ESR), and toxicity in 17 patients receiving long-term chrysotherapy

\begin{tabular}{|c|c|c|c|c|c|c|c|c|}
\hline \multirow[t]{2}{*}{ Patient no. } & \multirow[t]{2}{*}{ Gold salt } & \multirow{2}{*}{$\begin{array}{l}\text { Dose/interval } \\
m g / w k s\end{array}$} & \multirow[t]{2}{*}{ Total dose $\mathrm{mg}$} & \multicolumn{3}{|l|}{$\mu \mathrm{g}$ gold $/ 100 \mathrm{ml}$} & \multirow{2}{*}{$\begin{array}{l}E S R \\
m m / h\end{array}$} & \multirow{2}{*}{$\begin{array}{l}\text { Side } \\
\text { effects }\end{array}$} \\
\hline & & & & $\begin{array}{l}\text { Washed RBC } \\
10 \times 10^{12} / l\end{array}$ & $\begin{array}{l}\text { Whole** } \\
\text { blood }\end{array}$ & $\begin{array}{l}\text { Cell-rich** } \\
\text { plasma }\end{array}$ & & \\
\hline $\begin{array}{r}1 \\
2 \\
3 \\
4 \\
5 \\
6 \\
7 \\
8 \\
9 \\
10 \\
11 \\
12 \\
13 \\
14 \\
15 \\
16 \\
17\end{array}$ & $\begin{array}{l}M \\
S \\
S \\
S \\
S \\
M \\
S \\
S \\
M \\
S \\
S \\
M \\
M \\
M \\
S \\
S \\
S\end{array}$ & $\begin{array}{l}10 / 2 \\
50 / 4 \\
50 / 4 \\
25 / 4 \\
50 / 4 \\
20 / 2 \\
50 / 2 \\
50 / 4 \\
20 / 2 \\
50 / 4 \\
25 / 2 \\
10 / 2 \\
20 / 4 \\
20 / 1 \\
50 / 4 \\
50 / 4 \\
25 / 2\end{array}$ & $\begin{array}{l}1195 \\
6870 \\
7555 \\
1050 \\
1875 \\
1440 \\
9375 \\
9350 \\
1255 \\
7175 \\
2585 \\
3100 \\
1795 \\
1750 \\
3325 \\
3350 \\
8105\end{array}$ & $\begin{array}{r}0 \\
0 \\
0 \\
0 \\
0 \\
4 \\
4 \\
9 \\
11 \\
17 \\
20 \\
21 \\
27 \\
36 \\
56 \\
73 \\
88\end{array}$ & $\begin{array}{r}79 \\
56 \\
40 \\
36 \\
56 \\
75 \\
102 \\
41 \\
48 \\
- \\
68 \\
35 \\
112 \\
46 \\
44 \\
132\end{array}$ & $\begin{array}{r}112 \\
81 \\
75 \\
52 \\
88 \\
118 \\
144 \\
61 \\
72 \\
29 \\
66 \\
94 \\
37 \\
150 \\
40 \\
27 \\
135\end{array}$ & $\begin{array}{r}20 \\
96 \\
37 \\
5 \\
5 \\
50 \\
29 \\
56 \\
25 \\
7 \\
8 \\
23 \\
63 \\
27 \\
26 \\
32 \\
51\end{array}$ & $\begin{array}{l}0 \\
0 \\
0 \\
0 \\
0 \\
0 \\
0 \\
0 \\
0 \\
0 \\
0 \\
0 \\
0 \\
0 \\
\text { Dermatitis } \\
\text { Dermatitis } \\
\text { Severe joint } \\
\text { pain }\end{array}$ \\
\hline
\end{tabular}

$M=$ Myocrisin. $S=$ Sanocrysin. $R B C=$ red blood cells. $*$ The precision of each gold concentration is $\pm 2 \mu \mathrm{g} / 100 \mathrm{ml}$ or less. $* *$ The precision of each gold concentration is $\pm 5 \mu \mathrm{g} / 100 \mathrm{ml}$ or less. SI conversion: $\mathrm{gold} \mu \mathrm{g} / \mathrm{l}=\mu \mathrm{g} / 100 \mathrm{ml} \times 10$. 
the activity of the disease as measured by ESR at the time of investigation. It is noteworthy, however, that a strong correlation between erythrocyte gold concentration and toxic reactions was found. The concentration of gold in erythrocytes was significantly higher in patients with toxic reactions than in those patients without toxic reactions $(P<0 \cdot 01)$. All patients with an erythrocyte gold concentration smaller than or equal to $36 \mu \mathrm{g} / 100 \mathrm{ml}$ of washed erythrocyte fraction showed no toxic reactions, while all patients with an erythrocyte gold concentration larger than or equal to $56 \mu \mathrm{g} / 100 \mathrm{ml}$ had current toxic reactions (Table 1). Patients 15 and 16 had dermatitis, and the patient 17 suffered such severe and prolonged joint pain in relation to the gold injections that it was necessary to reduce the gold dosage by $50 \%$ to enable the gold therapy to continue. Although the number of patients in the toxic group is small and a larger group needs to be studied for confirmation of these results, it is statistically significant that toxic reactions developed when the erythrocyte gold concentration exceeded a critical value about $40-50 \mu \mathrm{g} / 100 \mathrm{ml}(400-500 \mu \mathrm{g} / \mathrm{l})$ of washed erythrocyte fraction.

With respect to plasma and whole blood gold concentrations no correlation to activity of the disease was seen. Similarly, there were no significantly raised gold concentrations in plasma and whole blood in the 3 patients suffering from toxic reactions $(\mathbf{P}>0 \cdot 1)$.

Table 3 Comparison between gold concentrations in erythrocytes $(R B C)$ determined by an indirect and a direct method

\begin{tabular}{lllll}
\hline Patient no. & $\mu g \mathrm{Au} / 100 \mathrm{ml}$ of whole blood & \\
\cline { 2 - 5 } & $\begin{array}{l}\text { Whole } \\
\text { blood }\end{array}$ & $\begin{array}{l}\text { Cell-rich } \\
\text { plasma }\end{array}$ & $\begin{array}{l}R B C^{*} \\
\text { (indirect) }\end{array}$ & $\begin{array}{l}\text { RBC } \\
\text { (direct) }\end{array}$ \\
\hline 1 & 79 & 79 & 0 & 0 \\
2 & 56 & 53 & 3 & 0 \\
3 & 40 & 47 & -7 & 0 \\
4 & 36 & 31 & 5 & 0 \\
5 & 56 & 51 & 5 & 0 \\
6 & 75 & 74 & 1 & 2 \\
7 & 102 & 95 & 7 & 2 \\
8 & 41 & 37 & 4 & 4 \\
9 & 48 & 42 & 6 & 5 \\
10 & - & 17 & - & 8 \\
11 & - & 37 & -12 & 12 \\
12 & 68 & 58 & 10 & 10 \\
13 & 35 & 23 & 12 & 13 \\
14 & 112 & 90 & 22 & 17 \\
15 & 46 & 22 & 24 & 29 \\
16 & 44 & 15 & 29 & 34 \\
17 & 132 & 84 & 48 & 41 \\
\hline
\end{tabular}

*The difference between whole blood and plasma gold concentrations corrected for haematocrit.

**The gold concentration of separated washed erythrocyte fraction corrected for blood erythrocyte count.

SI conversion: gold $\mu \mathrm{g} / \mathrm{l}=\mu \mathrm{g} / 100 \mathrm{ml} \times 10$.
We found that the gold concentrations in erythrocytes determined by an indirect and a direct method corresponded well with each other (Table 3). However, owing to the small amount of gold separating the toxic from the nontoxic group it is necessary to use the more precise direct method to investigate the relationship between erythrocyte gold concentration and toxicity.

\section{Discussion}

The present results are in agreement with the data of Smith et al., ${ }^{12}$ who found significant quantities of gold in the erythrocytes in 6 out of 16 patients on chrysotherapy, using neutron activation analysis.

Our findings differ from those of Freyberg et al., ${ }^{16}$ who were unable to detect gold in erythrocytes using a less sensitive colorimetric technique. Lawrence, ${ }^{1}$ using radioactive gold, found an average red cell concentration of gold about one-quarter of the plasma level on the first day after administration but did not state the procedures used for separating and washing the cells. Kamel et al., ${ }^{13}$ using atomic absorption spectrometry, found $4 \%$ of the total blood gold in a 'cell fraction', containing fibrinogen, plateles, and red and white cells, with not less than $90 \%$ in the white cells. Francois et al., ${ }^{14}$ using neutron activation analysis, found that the blood cell gold concentration in 4 patients was $2-4 \%$ of plasma concentration. When a small number of patients is investigated it will be a matter of chance whether the patients chosen have no gold or measurable quantities of gold associated with the red blood cells. In addition the different methods used (direct and indirect), the varying separation procedures, especially the seemingly neglected control of the separated erythrocyte concentration, and the varying sensitivity and precision of the technique used for the gold assay could explain the discrepancies of previous studies.

The seemingly strange observation that gold concentration in erythrocytes varied from 0 to 88 $\mu \mathrm{g} / 100 \mathrm{ml}$ of erythrocyte fraction unrelated to plasma gold concentrations might be explained by the following hypothesis. (1) The amount of gold incorporated into erythrocytes depends on the concentration of available gold in the bone marrow. (2) The amount of tissue gold depends, among other factors (heterogeneous tissue gold distribution), on the gold binding capacity of the plasma proteins. This binding capacity varies between and within individuals owing to variations in the concentration of plasma proteins and, perhaps more important, to interactions with different drugs. It may be of particular interest that a correlation 
was found between a high concentration of gold in the red cell fraction and current toxicity. In agreement with the hypothesis it would not be unexpected if, in excess of a certain amount of gold (threshold value), toxic reactions appeared.

It is worth noting that retrospective analysis of the patients studied showed no obvious differences with respect to previous incidence and severity of adverse reactions. This might support the interpretation that the amount of gold in the red cell fraction reflects a certain actual concentration of gold in the bone marrow rather than an individual ability or inability to incorporate gold into erythrocytes. This question, however, needs to be elucidated by appropriate prospective studies.

It is uncertain whether gold is bound to the surface of the red cells in the circulation or is incorporated into the red cell precursors in the bone marrow. The last possibility, suggested and supported by the observations of Smith et al., ${ }^{12}$ is consistent with our data. In accordance with previous reports ${ }^{2}$ 5-7 we found no correlation between whole blood and plasma gold concentrations and current toxicity.

Our results indicate that the quantitative determination of gold in erythrocytes might provide a useful warning of impending toxic reactions during chrysotherapy. Contrary to this, the determination of gold in whole blood and plasma does not appear to be a useful guide to safe therapy.

We thank Mrs Inge Bihlet for her skilful technical assistance.

\section{References}

1 Lawrence J S. Studies with radioactive gold. Ann Rheum Dis 1961 ; 20 : 341-50.

2 Gerber R C, Paulus H E, Bluestone R, Pearson C M. Clinical response and serum gold levels in chrysotherapy. Ann Rheum Dis 1972; 31: 308-10.

3 Mascarenhas B R, Granda J L, Freyberg R H. Gold metabolism in patients with rheumatoid arthritis treated with gold compounds-reinvestigated. Arthritis Rheum 1972; 15: 391-402.

- Jessop J D, Johns R G S. Serum gold determinations in patients with rheumatoid arthritis receiving sodium aurothiomalate. Ann Rheum Dis 1973; 32: 228-32.

5 Rubinstein H M, Dietz A A. Serum gold. II. Levels in rheumatoid arthritis. Ann Rheum Dis 1973; 32: 128-32.

- Yamanaka K, Miyagi S, Mita M, Yamasaki S. Therapeutic response and serum gold levels in long-term gold therapy. Excerpta Medica International Congress Series, No. 299, XIIIth International Congress of Rheumatology 1973: Abstr. 137.

7 Gottlieb N L, Smith P M, Smith E M. Pharmacodynamics of ${ }^{197} \mathrm{Au}$ and ${ }^{195} \mathrm{Au}$ labeled aurothiomalate in blood. Arthritis Rheum 1974; 17: 171-83.

8 Billings R, Grahame R, Marks V, Wood P J, Taylor A. Blood and urine gold levels during chrysotherapy for rheumatoid arthritis. Rheumatol Rehabil 1975; 14: 13-8.

- Krusius F E, Markkanen A, Peltola P. Plasma levels and urinary excretion of gold during routine treatment of rheumatoid arthritis. Ann Rheum Dis 1970; 29: 232-5.

10 Lorber A, Atkins C J, Chang C C, Lee Y B, Starrs J, Bovy R A. Monitoring serum gold values to improve chrysotherapy in rheumatoid arthritis. Ann Rheum Dis 1973; 32: 133-9.

11 Lorber A, Simon T M, Leeb J, Carrol P E, Jr. Chrysotherapy: Pharmacological and clinical correlates. $J$ Rheumatol 1975; 2: 401-10.

12 Smith P M, Smith E M, Gottlieb N L. Gold distribution in whole blood during chrysotherapy. J Lab Clin Med 1973; 82: 930-7.

13 Kamal H, Brown D H, Ottaway J M, Smith W E. Determination of gold in blood fractions by atomicabsorption spectrometry using carbon rod and carbon furnace atomisation. Analyst 1976; 101: 790-7.

14 Francois P E, Goldberg I J L, Lawton K, Al-Ani D T, Redding $\mathrm{J} \mathbf{H}$. Distribution of gold in blood during chrysotherapy. Ann Clin Biochem 1978; 15: 324-5.

15 Pedersen S M, Graabæk P M. A unified method for the determination of gold in biological fluids by flameless atomic absorption spectroscopy. Scand J Clin Lab Invest 1977; 37: 91-4.

16 Freyberg R H, Block W D, Levey S. Metabolism, toxicity and manner of action of gold compounds used in the treatment of arthritis. I. Human plasma and synovial fluid concentration and urinary excretion of gold during and following treatment with gold sodium thiomalate, gold sodium thiosulfate, and colloidal gold sulfide. J Clin Invest 1941; 20: 401-12. 